GLOBAL JOURNAL OF ENGINEERING RESEARCH VOL 13, 2014: 21-34

COPYRIGHT@ BACHUDO SCIENCE CO. LTD PRINTED IN NIGERIA. ISSN 1596-292x www.globaljournalseries.com; Info@globaljournalseries.com

\title{
ANALYSIS OF COLIFORM BACTERIA IN WSPS AT ALSCON USING MACCONKEY BROTH AND LOCALLY MADE SOLUTION
}

\author{
E. C. UKPONG AND UDECHUKWU JOHN ABARAUGU
}

\begin{abstract}
Enumeration of coliform bacteria in wastewater was carried out by comparing between imported Macconkey broth solution and the locally prepared solution type. Wastewater samples were obtained from four Waste Stabilization ponds (WSPs) at the Aluminium smelting company located at Ikot Abasi Local Government Area of Akwa Ibom State. The results of the Analysis showed that the imported media yielded higher numbers of coliform bacteria per $100 \mathrm{ml}$, as compared to the locally prepared media. Two methods where used for this analysis namely: the membrane Filtration Technique (MFT) and the Multiple Tube Technique (MTT). The MFT was more precise, simple and faster in enumerating coliofrm bacteria per $100 \mathrm{ml}$ as compared with the MTT method. The two methods (MTT and MFT) was used to determine the amount of coliform present in two different samples each of locally male solution and imported Macckonkey broth solution. The Average results obtained for sample 1 from the MTT method for ponds 01 to ponds 04 respectively for locally made solution are 255.75, 268,271.25, and 262 , while that from imported solution are 293.75, 312, 317, and 2995. also the average result from MFT for locally made solution are 246, 260.5, 257.5 and 247.5; while that for imported solution is $265.25,282,278$, and 267.75 all in multiples of 1000 . For sample 2, the results obtained from MTT method from ponds 1 to 4 for locally mixed solution are 178.25, 192.5, 184.5 and 177.5, while that of imported macConkey broth solution are $158,167,5,171.25$ and 162 . Also that of MFT for locally mixed solution are 206.25, 227,206.25 and 211.75, while that of imported macConkey solution are. $186,201.75,187.5$ and 187.5 all in multiples of 1000 per $100 \mathrm{ml}$ the other average results from pond 1 to 4 are obtained from the different compartments of each pond, this includes the pH of sample (6.853, $6.6 .55,6.378$ and 6.918), The TDS $(81.125,98.25,116.575$, and 129.010), the DO $(2.893,2.585,2.58$, and 2.798), the BOD (1.748, 1.435, 1.430, and 1.648), The COD (98, 115.25, 124,70 and 131.160), conductivity (162.7, 197, 233.4 and 258.05), and Temperature in celcius $(28.25,29.145,29.155$, 28.685).
\end{abstract}

KEYWORDS: Total Coliform, waste stabilization pond, bacteria, wastewater and Macconkey broth.

\section{INTRODUCTION}

This analysis involves the determination of physical, chemical and biological characteristics of the wastewater samples at the Aluminum smelting company located at Ikot Abasi Local Government Area of Akwa lbom State. The primary analysis is for indicator organisms rather than the pathogens that might cause concern.
Indicator organisms are bacteria such as non-specific coliforms, Esherichia Coli and Pseudomonas aeruginosa that are very commonly found in the human or animal gut and which, if detected, may suggest the presence of sewage.

Indicator organisms are used because even when a person is infected with more pathogenic bacteria, they will still be excreting many millions times more indicator organisms

E. C. Ukpong, Department of Civil Engineering, Faculty of Engineering, University of Uyo, Uyo, Nigeria. Udechukwu John Abaraugu, Department of Civil Engineering, Faculty of Engineering, University of Uyo, Uyo, Nigeria. 
Bacteria in wastewater are generally classified in different ways, but the coliform bacteria in wastewater are often described as being aerobic (needing oxygen), anaerobic (not needing oxygen) and facultative (can survive in the presence or absence of oxygen). Other systems of classification include their shapes, which could be spherical, rod shaped, bent, or curved shapes.

However, bacteria are unicellular plants varying in size from 0.5 to 3 microns, and without chlorophyll. They take soluble food and convert it into new cells. Reproduction is by binary fission (Agnawamba, 2001). Bacteria are sensitive to $\mathrm{pH}$ and temperature.

Testing for the presence of coliforms is the standard way to indicate the possible additional presence of more harmful pathogens in food, beverages and water. While some of these "indicate bacteria" are frequently present in our everyday lives to a certain extent, they themselves usually only cause issue when they reach elevated numbers, such as with Escherichia Coli bacteria. It is present in most warmblooded animals including people, and exists harmlessly in most cases. When numbers elevate, or certain strains are introduced however, this is when illness is more likely to occur.

\subsection{Significant Of Coliforms in Wastewater}

Monitoring for total coliforms at the treatment plant and in the distribution and storage system is carried out to provide information on the adequacy of drinking water treatment and on the microbial condition of the distribution system. The presence of total coliforms in water or waste water leaving any treatment plant signifies inadequate treatment has taken place and therefore additional actions such as notifying the responsible authorities, investigating the cause of the contamination, and implementing corrective actions; which could include issuing a boil water advisory.

In the distribution and storage system, when water tested immediately post-treatment is free of total coliforms, indicates water quality degradation, possibly via bacterial regrowth or post treatment contamination. In municipal-scale systems, the detection of more than $10 \%$ of samples in a given sampling period, or of consecutive samples from the same site, that are positive for total coliforms indicates changes in the quality of the water and a need for follow-up action to be initiated. In residential scale systems where there is little or no distribution system, presence of any total coliforms should trigger follow-up actions to investigate the cause of the positive results.

Since the wastewater from the WSPs are sources of fecal contamination to both surface and underground water. It becomes very pertinent to check the degree of treatment at the ponds before it discharges into either the surface or underground waters to contaminate it.

\subsection{Objective of the Study}

$>\quad$ To determine the presence and degree of pathogen in the WSPs at ALSCON since most pathogens that can contaminate water supplies come from the feces of humans or animals.

$>\quad$ Reduce the cost of testing for the pathogens since coliform test is considerably very cheap compared to other methods of testing for pathogens.

$>\quad$ Reducing the time as well as making the test for pathogens simplier by the use of imported macckonkey broth, this also enhances the accuracy of results produced for the coliform test as compared with the locally made solution used for tests of coliform.

\subsection{Total Coliform (TC)}

Total coliforms are those bacteria that can be found everywhere in nature. They could be found in the soil, air and water; hence, they are not specific to feacal materials only like the feacal coliforms. Knowledge of total Coliform is very important in wastewater treatment as the bacteria degrade the organic waste to biomas (sludge) and water.

Their presence in water indicates that the water has been contaminated by waste material from agricultural waste, run-off, industrial waste, sewage and even dissolved particles from the air. Their presence in water does not mean that they cause disease directly but signifies that the water has been contaminated and could pose possible health threat to individuals.

\subsection{Feacal Coliform (FC)}

Feacal coliforms are those bacteria that live in the intestinal tract of man and other warm 
blooded animals. Their presence in water indicates recent feacal contamination of that water by man or other warmed blooded animals. The most common member of feacal Coliform is the Escherichia coli (E.coli), which is used as indicator to detect pathogens in the water, since the direct detection of the pathogens is always very difficult. Although these bacteria do not cause disease directly but high quantity of it suggests the presence of disease causing micro organisms.

\subsection{Study Area}

The wastewater used for this work was obtained from the waste stabilization pond of the Aluminum Smelter Company of Nigeria (ALSCON), Ikot Abasi. The pond at ALSCON consists of three Facultative ponds, measuring $150 \mathrm{~m} \times 50 \mathrm{~m} \times 1.5 \mathrm{~m}$ in series and a maturation pond measuring $120 \mathrm{~m} \times 60 \mathrm{~m} \times 1.2 \mathrm{~m}$. Ikot Abasi Local Government Area is located in Akwa Ibom State of Nigeria and is an industrial town with a population of over 700,000 people. The main occupation of the area is farming. Figure 1 show the map of the Akwa Ibom State showing the study area. 


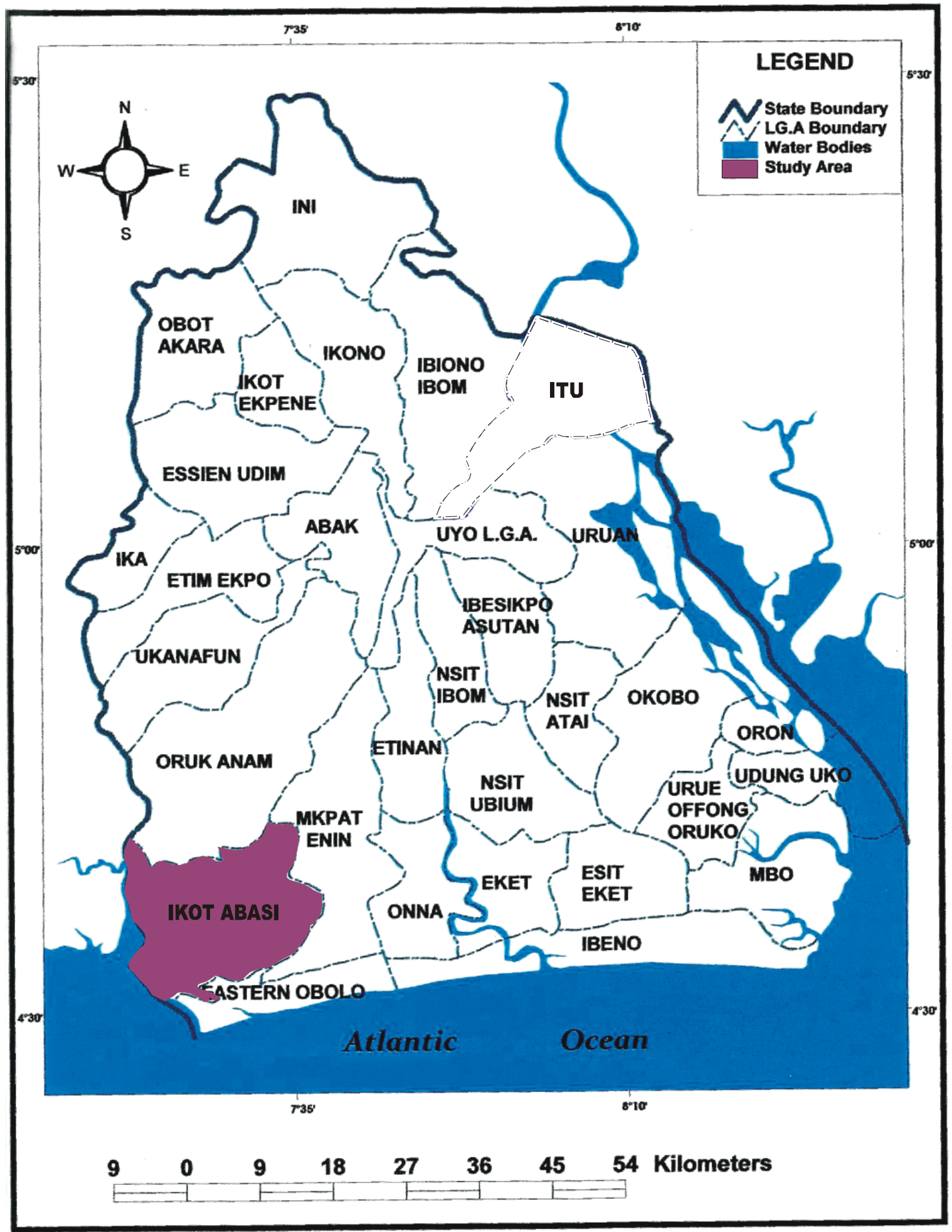

Figure: 1: Map of Akwa Ibom State showing Ikot Abasi L.G.A - the study area 


\subsection{Characteristics of wastewater \\ Water is a simple chemical compound} with a chemical formula of $\mathrm{H}_{2} \mathrm{O}$. Most analysis of wastewater sample is aimed at determining the impurity level and the type of treatment required for effective purification before it is used.

The physical characteristics include; temperature, taste, odour, colour, turbidity, dissolved solid etc. The chemical characteristics which are defined in terms of organic and inorganic matter present in the water include; $\mathrm{pH}$, hardness, alkalinity, acidity, chlorides, dissolved oxygen, biochemical oxygen demand (BOD), chemical oxygen demand (COD). The biological characteristics include; fecal Coliform (FC), total Coliform (TC) etc.

Attempts have been made in recent time to correlate the physical and biological characteristics of certain members of Coliform bacteria with human feacal contamination in an attempt to sharpen the sanitary significance of such organism.

\subsection{Classification of Coliform Bacteria}

Bacteria are generally classified in different methods, but the Coliform bacteria in wastewater are often described as being aerobic (needing oxygen), anaerobic (not needing oxygen) and facultative) can survive in the presence or absence of oxygen). Other system of classification include their shapes, which could be spherical, rod shape bent or curved shapes etc.

\subsection{MATERIALS AND METHOD}

\subsection{Source and Collection of Samples}

The wastewater samples were collected from the waste Stabilization pond of the Aluminum Smelter Company of Nigeria (ALSCON), Ikot Abasi. The company has four WSP namely; 01, 02, 03 and 04. Each of this pond consist of three facultative ponds in series and a maturation pond.

Four set of samples were taken from each of the pond (i.e. from 01, 02 etc.) and the Total and feacal coliforms were enumerated using the standard MPN method and membrane filtration method (APHA, 1992).
The sample was conveyed to the laboratory with extreme care and the bacteriological test was carried out within 24 hours of the collection of the samples to ensure that the bacteria to be tested for do not die off. Samples were stored in refrigerator at $4^{\circ} \mathrm{C}$ to avoid biological activities.

\subsection{Sterilization}

All the glassware used in the work were wrapped in aluminum foil and sterilized in a hot box oven (Gallenkamp) at $160^{\circ} \mathrm{C}$ for one hour. The plastic equipment used in this analysis were sterilized in $90 \%$ ethanol for two hours and dried in an incubator at $45^{\circ} \mathrm{C}$. The surface of the work bench where the practical was carried out was disinfected with $95 \%$ ethanol before the commencement of the experiment.

\subsection{Preparation of Culture media/reagent}

The culture media used was the MacConkey Broth, with the following composition: peptone $(20 \mathrm{~g})$, lactose $(\mathrm{lOg})$, Bile salt $(5 . \mathrm{Og})$, sodium chloride $(5 . \mathrm{Og})$, neutral red $(0.075 \mathrm{~g})$. The optimum $\mathrm{pH}$ use was $7.4 \div 0.2^{\circ} \mathrm{C} .40$ grams of the media was dissolved in one (1) litre of distilled water and was thoroughly mix and then distributed into screw capped bottle fitted with Durham tube. Sterilization is done using autoclave at $121^{\circ} \mathrm{C}$ for 15 minute under a pressure of $15 \mathrm{lb}$ per square inch.

\subsection{Methods of Analyzing Coliform Bacteria}

Two techniques are commonly used to detect the presence of Coliform bacteria in water. The first of these is called the "multiple fermentation tube" or "most probable number" technique. In this method measured portions of a water sample are placed in test-tubes containing a culture medium. The tubes are then incubated for a standard time at a standard temperature. In the second technique, a measured volume of sample is passed through a fine filter that retains bacteria. The filter is then placed on culture medium and incubated. This is called the "membrane filter" technique. Features of the two techniques are compared in Table 1.0.A 
Table 1.0.A: Comparison of methods for analysis of coliform bacteria

\begin{tabular}{|c|c|}
\hline Multiple fermentation tube technique & Membrane filter technique \\
\hline Slower; require 48 hours for a positive & $\begin{array}{l}\text { More rapid; quantitative results in or } \\
\text { presumptive positive about } 18 \text { hours }\end{array}$ \\
\hline More labour-intensive & Less labour-intensive \\
\hline Require less culture medium & Require more culture medium \\
\hline Require more glassware & Require less glassware \\
\hline $\begin{array}{l}\text { Result obtained indirectly by statistical } \\
\text { approximation (low precision) }\end{array}$ & $\begin{array}{l}\text { Results obtained directly by colony count (high } \\
\text { precision) }\end{array}$ \\
\hline Not readily adaptable for use in the field & Readily adapted for use in field \\
\hline Applicable to all types of water & Not applicable to turbid waters \\
\hline $\begin{array}{l}\text { Consumables readily available in most } \\
\text { countries }\end{array}$ & Cost of consumables is high in many countries \\
\hline $\begin{array}{l}\text { May give better recovery of stressed or } \\
\text { damaged organisms in some circumstances }\end{array}$ & \\
\hline
\end{tabular}

Source: APHA, 1992

\subsection{Most Probable Number (MPN)}

This method has been extensively use for the analysis of drinking water for many years with satisfactory results. It is the only procedure that can be used if water samples are very turbid or if semi-solids such as sediments or sludge are to be analyzed. It is a statistical estimation of the concentration of coliform organism present in $100 \mathrm{ml}$ of the sample. Agañwamba (2001), stated that the coliform organisms comprise of all the aerobic, anaerobic, facultative, gram negative, non-spore forming rod-shaped bacteria which ferment lactose with gas formation within 48 hoursat $35^{\circ} \mathrm{C}$.

APHA, (2005) used the MPN method to enumerate for total colfform and E.coli, in their study of the concentration of enteric bacteria in reservoir feeder. They used Glutamate media modified with minerals for the presumptive enumeration of total coliform. Peptone water and lactose broth were used for the confirmation of E.coli presence. The result showed significant increases in enteric bacterial concentration in 9 out of the 11 reservoir feeder streams examined. They suggested that a flushing mechanism might be aiding the transports of enteric bacteria into upland reservoirs. The MPN method according to APHA standard is divided into three stages;

1. Presumptive test using MacConkey broth and the result estimated using MacCrady's probability table.

2. Confirmed test otherwise called the Ejikam's test use to ascertain whether the coliform detected in the presumptive test are plated on Eosin methylene blue medium.

3). Complete test, use for the characterization of coliform by metallic sheen which can be differentiated from others by their colonies.

Bartram, (2000) while working on inhibition of coliform by bacteriocinlike substance in drinking water distribution system came up with the possible causes of their inability to detect coliform by MPN method. These causes were:

1) Interaction of non-coliform bacteria with coliform bacteria resulting in nutritional competition.

2) Mechanical injury which cumulatively suppressed coliform growth in standard MPN test.

3) Non-lactose fermenting bacteria pollute water and a strain of antibiotic producing bacilli inhibiting growth of coliform bacteria.

Both Olson and Fischer while working on enhanced accuracy of coliform testing in sea water by modification of the MPN method and the antagonistic effect of aerobic bacteria on coli, suggested that the failure of coliform bacteria to produce gas from lacotose fermentation in the presumptive portion of the test may be a function of bacteriocin absorption and release, which can result in a series underestimation of bacteriological quality of water supply. They do eventually recover this ability in the confirmed 
test. However, the major limitation of the MPN method is underestimation of both the incidence and number of coliform in a sample of water.

Agumwamba (2001) stated that the MPN test may be determined by using;

1) The MPN model

2) Thomas approximate method or

3) Statistical tables.

The MPN model is given by:

$Y=1 / a\left[\left(\quad \operatorname{lexpN}_{1} \lambda\right)^{P}\left(\exp -N_{1} \lambda\right){ }^{q}\right][\quad(1-\exp -$ $\left.N 2 \lambda)^{r}(\exp -N 2 \lambda)^{s}\right]\left[\left(1-\exp -N^{3} \lambda\right)^{t}\left(\exp -N_{3} \lambda\right)^{u}\right]$.

Where $N_{1}, N_{2}, N_{3}=$ various size of portion examine

$p r, t=$ no of portion of respective size giving positive tube for Coliform

$\mathrm{q}, \mathrm{s}, \mathrm{u}=$ no of portion of respective size giving negative test for coliform

$\begin{array}{lll}\lambda & = & \text { concentration of Coliform in } \mathrm{ml} \\ \mathrm{Y} & = & \text { Probability of occurrence of } \mathrm{a} \\ \mathrm{a} & = & \text { particular result. } \\ \mathrm{a} & \text { constant }\end{array}$

The MPN is determine by selecting the values of $A$ that will maximize $Y$. In the Thomas method MPN is estimated by;

MPN = $100 \times$ number of positive tube

[(volume of all negative portions) (volumes of all portion)]"0.5

For statistical table the MPN is determine by reading the values from already prepared tables based on the number of positive tubes in the multiple dilutions.

\subsection{Membrane Filtration Method}

The membrane filter method gives a direct count of total Coliform and feacal Coliform present in a given sample of water. The membrane filtration technique is based on the fact that special filter discs with small pore size (0.2-0.8um) will retain bacteria cells which can be made to growth out to visible colonies by incubating the filter discs on a nutrient medium e.g. the Endo medium, which can cause the growth of recognizable coliform colonies that can be counted after incubating at $35^{\circ} \mathrm{C}$ within 24 hours. The MF is easy to perform and highly reproducible, as compare with the MPN technique. The MF method yields a faster result with greater precision. Membrane filtration was first used in Britain in 1953 for the enumeration of total coliform in water (Taylor, 1957). Muller in Germany used membrane filters for the analysis of portable water for Coliform. Bartram, et. al., (2000). He also reported that by the early 50's membrane filtration was a practical alternative to the MPN approach, although it's inability to demonstrate gas production with membrane was considered a major draw back. The membrane filter- most probable number (MF-MPN) procedure were used by Altherholt, et. al., (2003). In laboratories studies of estuarines water to recover coliform and feacal coliform comparable to those obtained by the standard multiple tube (MPN) procedure.

Bartram, (2000). Studied chlorine resistant pattern of bacteria from drinking water distribution system using the MF technique which they asserted, allowed for rapid and qualitative assessment of the chlorine resistance pattern of bacteria population obtained directly from an aquatic environment. The ME procedure also facilitates the detection, qualitative enumeration and axenic isolation of highly chlorine resistant sensitive cell types which may be present in a particular water supply.

Altherholt et. al., (2003). used MF technique to study the effect of turbidity on chlorination efficiency and bacterial persistence in drinking water. Total coliform were enumerated by the modified ME technique which include an added resuscitation step, they used the lauryl tryptose broth saturated pads and M Endo Agar and their result were in conformity with those published by the American Public Health Association (APHA) on standard method for the examination of water and waste water. However, this technique is unsuitable for water containing very high level of suspended material, sludge's and sediments all of which could blocked the filter before an adequate volume of water will pass through. Result of membrane filtration is calculated from the following formula;

Number of colonies per $100 \mathrm{ml}=$
\[ \frac{\text { no of colonies } \times 100}{\text { Volume of filtered }} \]

The colonies count at this stage are presumed to be Coliform bacteria (presumptive result) 
Presentation of result

The result of relevant tests carried out during this study which gave values for DO, BOD, TDS, pH, feacal Coliform, Total Coliform, temperature etc. are presented in Table 1, 2, 3, 4, 5, 6 and also in Figures respectively as shown below;

TABLE 1: Result of Physiochemical Parameters for Pond 01 (Chambers $A$ to D)

\begin{tabular}{|c|c|c|c|c|c|}
\hline \multirow[t]{2}{*}{ PARAMETERS/ UNITS } & \multicolumn{5}{|c|}{ POND 01} \\
\hline & A & B & C & D & MEAN \\
\hline $\mathrm{pH}$ & 6.57 & 6.8 & 6.94 & 7.1 & 6.853 \\
\hline TDS MG/L & 76.5 & 80 & 83 & 85 & 81.125 \\
\hline$\overline{D O} \mathrm{MG} / \mathrm{L}$ & 2.8 & 3 & 2.77 & 3 & 2.893 \\
\hline BOD MG/L & 1.67 & 1.85 & 1.62 & 1.85 & 1.748 \\
\hline COD MG/L & 92 & 98 & 100 & 102 & 98 \\
\hline Conductivity Us/cm & 154.8 & 160 & 166 & 170 & 162.7 \\
\hline TEMP ${ }^{\circ} \mathrm{C}$ & 28.6 & 28 & 28.3 & 28.1 & 28.25 \\
\hline
\end{tabular}

TABLE 2: Results of Physiochemical Parameters for Pond 02 (Chambers A to D)

\begin{tabular}{|l|l|l|l|l|l|}
\hline PARAMETERS/UNITS & POND 02 & \multicolumn{1}{l|}{} \\
\hline & A & B & C & D & MEAN \\
\hline pH & 7 & 6.4 & 6.45 & 6.35 & 6.55 \\
\hline TDS MG/L & 90 & 98 & 100 & 105 & 98.25 \\
\hline DO MG/L & 2.6 & 2.56 & 2.6 & 2.58 & 2.585 \\
\hline BOD MG/L & 1.45 & 1.41 & 1.45 & 1.43 & 1.435 \\
\hline COD MG/L & 110 & 115 & 117 & 119 & 115.25 \\
\hline Conductivity Us/cm & 180 & 196 & 201 & 211 & 197 \\
\hline TEMP. ${ }^{\circ} \mathrm{C}$ & 29 & 29.33 & 29.1 & 29.15 & 29.145 \\
\hline
\end{tabular}

TABLE 3: Result of total coliform for imported and locally prepared MacConkey Broth

\begin{tabular}{|c|c|c|c|c|c|}
\hline \multicolumn{2}{|c|}{ Pond type } & \multicolumn{4}{|c|}{ Total coliform per $100 \mathrm{ml}$} \\
\hline & & \multicolumn{2}{|c|}{ Local } & \multicolumn{2}{|l|}{ Imported } \\
\hline & & MTT (in $10^{3}$ ) & MFT (in $10^{3}$ ) & MTT (in $10^{3}$ ) & MFT (in $10^{3}$ ) \\
\hline \multirow[t]{4}{*}{1} & A & 260 & 240 & 300 & 260 \\
\hline & $B$ & 250 & 245 & 285 & 265 \\
\hline & C & 263 & 250 & 305 & 270 \\
\hline & D & 250 & 249 & 285 & 266 \\
\hline \multirow[t]{4}{*}{2} & A & 265 & 255 & 309 & 275 \\
\hline & $B$ & 270 & 260 & 315 & 280 \\
\hline & C & 265 & 263 & 310 & 285 \\
\hline & $\mathrm{D}$ & 272 & 264 & 315 & 288 \\
\hline \multirow[t]{4}{*}{3} & A & 270 & 259 & 315 & 279 \\
\hline & B & 275 & 248 & 320 & 268 \\
\hline & C & 270 & 260 & 315 & 280 \\
\hline & $\mathrm{D}$ & 270 & 263 & 318 & 285 \\
\hline \multirow[t]{4}{*}{4} & A & 258 & 255 & 290 & 275 \\
\hline & $B$ & 260 & 245 & 300 & 265 \\
\hline & C & 255 & 240 & 288 & 260 \\
\hline & D & 275 & 250 & 320 & 271 \\
\hline
\end{tabular}

Note; MTT $=$ Multiple Tube Technique

MFT $=$ Membrane Filtration Technique 
TABLE 3A: Result of Average Coliform bacteria Obtained from Locally Imported Solution.

\begin{tabular}{|l|l|l|l|l|}
\hline \multirow{2}{*}{ POND } & LOCALLY & IMPORTED \\
\cline { 2 - 5 } & MTT (in $10^{3}$ ) & MFT (in $10^{3}$ ) & MTT (in 10 ${ }^{3}$ ) & MF (in 10 ${ }^{3}$ ) \\
\hline Pond 1 & 255.75 & 246 & 293.75 & 265.25 \\
\hline Pond 2 & 268 & 260.5 & 312.25 & 282 \\
\hline Pond 3 & 271.25 & 257.5 & 317 & 278 \\
\hline Pond 4 & 262 & 247.5 & 299.5 & 267.75 \\
\hline
\end{tabular}

TABLE 4: Results of Physiochemical Parameters for Pond 03 (Chambers A to D)

\section{PARAMETERS/UNITS}

\begin{tabular}{|l|l|l|l|l|l|}
\hline & A & B & C & D & MEAN \\
\hline pH & 6.38 & 6.35 & 6.4 & 6.38 & 6.378 \\
\hline TDS MG/L & 107 & 110 & 120.6 & 128.7 & 116.575 \\
\hline DO MG/L & 2.59 & 2.58 & 2.56 & 2.59 & 2.580 \\
\hline BOD MG/L & 1.44 & 1.43 & 1.41 & 1.44 & 1.430 \\
\hline COD MG/L & 120 & 122 & 127 & 129.8 & 124.700 \\
\hline Conductivity Us/cm & 215 & 220 & 241.2 & 257.4 & 233.400 \\
\hline TEMP. ${ }^{\circ} \mathrm{C}$ & 29.05 & 29.2 & 29.25 & 29.12 & 29.155 \\
\hline
\end{tabular}

TABLE 5: Results of Physiochemical Parameters for Pond 04 (Chambers A to D)

\section{PARAMETERS/UNITS}

\begin{tabular}{|l|l|l|l|l|l|}
\hline & A & B & C & D & MEAN \\
\hline pH & 7.1 & 6.82 & 6.9 & 6.85 & 6.918 \\
\hline TDS MG/L & 125 & 127.84 & 130 & 133.2 & 129.010 \\
\hline DO MG/L & 2.9 & 2.83 & 2.76 & 2.7 & 2.798 \\
\hline BOD MG/L & 1.75 & 1.68 & 1.61 & 1.55 & 1.648 \\
\hline COD MG/L & 128 & 128.94 & 132.3 & 135.4 & 131.160 \\
\hline Conductivity Us/cm & 250 & 255.8 & 260 & 266.4 & 258.050 \\
\hline TEMP. C & 28.5 & 28.67 & 28.77 & 28.8 & 28.685 \\
\hline
\end{tabular}

Where; A, B, C, AND D are the Pond Chambers or Compartments

TABLE 6: Result of feacal coliform for imported and locally prepared MacCONKEY Broth.

POND TYPE

\begin{tabular}{|c|c|c|c|c|c|}
\hline \multicolumn{2}{|c|}{ POND IYPE } & \multirow{2}{*}{\multicolumn{2}{|c|}{ LOCAL }} & \multicolumn{2}{|c|}{ FAECAL CULIFURIVI PER TUOIVIL } \\
\hline & & & & \multicolumn{2}{|l|}{ IMPORTED } \\
\hline & & MTT & MFT (in $10^{3}$ ) & MTT (in $10^{3}$ ) & MFT (in $10^{3}$ ) \\
\hline \multirow[t]{4}{*}{1} & A & 175 & 200 & 160 & 180 \\
\hline & $\mathrm{B}$ & 180 & 210 & 155 & 185 \\
\hline & C & 178 & 215 & 163 & 190 \\
\hline & $\mathrm{D}$ & 180 & 200 & 156 & 189 \\
\hline \multirow[t]{4}{*}{2} & A & 190 & 220 & 165 & 195 \\
\hline & $\mathrm{B}$ & 195 & 225 & 170 & 200 \\
\hline & C & 190 & 230 & 165 & 205 \\
\hline & $\mathrm{D}$ & 195 & 233 & 170 & 207 \\
\hline 3 & $A$ & 198 & 202 & 170 & 199 \\
\hline \multirow[t]{7}{*}{4} & $B$ & 200 & 208 & 175 & 188 \\
\hline & C & 195 & 205 & 170 & 180 \\
\hline & $D$ & 200 & 210 & 170 & 183 \\
\hline & $A$ & 165 & 220 & 158 & 195 \\
\hline & $B$ & 175 & 210 & 160 & 185 \\
\hline & C & 180 & 200 & 155 & 180 \\
\hline & $D$ & 190 & 217 & 175 & 190 \\
\hline
\end{tabular}

FAECAL COLIFORM PER 100ML LOCAL 
TABLE 6A: Results of Average Coliform bacteria Obtained from Locally Imported Solutions.

\begin{tabular}{|c|c|c|c|c|}
\hline \multirow[t]{2}{*}{ POND } & \multicolumn{2}{|l|}{ LOCALLY } & \multicolumn{2}{|l|}{ IMPORTED } \\
\hline & MTT (in $10^{3}$ ) & MFT (in $10^{3}$ ) & MTT (in $10^{3}$ ) & MFT (in $10^{3}$ ) \\
\hline Pond 1 & 178.25 & 206.25 & 158 & 186 \\
\hline Pond 2 & 192.5 & 227 & 167.5 & 201.75 \\
\hline Pond 3 & 184.5 & 206.25 & 171.25 & 187.5 \\
\hline Pond 4 & 177.5 & 211.75 & 162 & 187.5 \\
\hline
\end{tabular}

\subsection{DISCUSSION OF RESULT}

From the table $1,2,4$ and 5 , it can be deduced that the averages for the following tests are: $\mathrm{pH} 6.675$, TDS $106.24 \mathrm{mg} / \mathrm{l}$ DO $2.714 \mathrm{mg} / \mathrm{l}$, BOD $1.565 \mathrm{mg} / \mathrm{l}$, COD $117.278 \mathrm{mg} / \mathrm{l}$, conductivity $212.788 \mathrm{mg} / \mathrm{cm}$ and temperature $28.809^{\circ} \mathrm{c}$. Meanwhile the maximum values of each of the parameters occurred as shown in the table as follow:

pH. 7.1 (occurred in pond 1 , chamber D), DO 3.0mg.l (occurred in pond 1, chambers $B$ and $D$ ), BOD $1.85 \mathrm{mg} / \mathrm{l}$ (occurred in pond 1 , chambers $B$ and D), COD $135.4 \mathrm{mg} / \mathrm{l}$ (occurred in pond 4 , chamber D), conductivity $266.4 \mathrm{mg} / \mathrm{l}$ (occurred in pond 4, chamber D), and Temperature $29.33^{\circ} \mathrm{C}$ (occurred in pond 2), chamber B).

The minimum values of the different parameters are also seen as shown: $\mathrm{pH} 6.35$ (pond 1, chamber D) and pond 3 chamber B) TDS $76.5 \mathrm{mg} / \mathrm{l}$ (pond 1, chamber A), DO $2.56 \mathrm{mg} / \mathrm{l}$ (pond 2 chamber $B$ and pond 3 chamber $C$ ), BOD $1.41 \mathrm{mg} / \mathrm{l}$ (pond 2, chamber $\mathrm{B}$ and pond 3 chamber C) COD 92mg/l (pond 1, chamber A), conductivity 154.8us/l (pond 1, chamber A), Temperature $28.0^{\circ} \mathrm{c}$ (Pond 1, chamber B).

From table $3 \mathrm{~A}$ (for sample 1 ) and $6 \mathrm{~A}$ (for samples 2) it can be deduced that the average colliform in each tank is as follows sample 1: pond $1\left(274.75 \times 10^{3}\right)$ and $255.875 \times 10^{3}$ for MFT), Pond 2 (290.125 $\times 10^{3}$ for MFT) and pond $4\left(280.75 \times 10^{3}\right)$ for MTT and 257.625 for MFT). Table 6A (Sample 2): Pond $1\left(168.125 \times 10^{3}\right)$ for MTT and $196.125 \times 10^{3}$ for MFT), Pond 2 (180.0 $\times 10^{3}$ for MTT and $214.375 \times 10^{3}$ Pond 3 $\left(195.375 \times 10^{3}\right)$ for MTT and $196.875 \times 10^{3}$ for MFT) Pond 4 (169.75 x $10^{3}$ for MTT and 199.625 $\times 10^{3}$ for MFT). Also for Table 3A (Sample 1), the maximum coliform $320 \times 10^{3}$ maximum coliform $320 \times 10^{3}$ for MTT is in Pond 3 , camber B and pond 4 chamber D, MFT $288 \times 10^{3}$ is in pond 2 chamber $D$ and the minimum $250 \times 10^{3}$ is shown in pond 1 chamber D for MTT and $240 \times 10 \times 10^{3}$ ponds 1 , chamber $A$ and pond 4 chamber $C$ for MFT as shown in table $3 \mathrm{~A}$.

For sample 2, the maximum coliform 200 $x 10^{3}$ is shown in pond 3 chamber $B$ and $D$ for MTT and $233 \times 10^{3}$ ponds 1 chamber $A$, Pond $A$, Pond 3 chamber $C$ and Pond 4 Chamber $C$ for MTT and $180 \times 10^{3}$ Ponds 1 chamber A, Pond 3 chamber $\mathrm{C}$ and Pond Chamber $\mathrm{C}$ showing in Table 6A.

From the results of the tests, there were decreases in the values of BOD, DO, TDJ and $\mathrm{pH}$. This may be attributed to the preliminary treatment of the wastewater, which led to the reduction in the concentration/strength of the wastewater. The low $\mathrm{pH}$ was as a result of the neutralization of the neutralization done during the preliminary treatment of the wastewater. The low BOD and Do may be as a result of preliminary removal of toxic favourable temperature substances, sedimentation, classification, detention time and the favourable temperature of the pond.

Figures 2and 3 shows the different variations in locally made and imported Mackonkey broth. From the result of the Analysis, membrane filtration technique (MFT) was found to be more precise, simple and quicker in the enumeration of coliform bacteria as compared with the multiple tube technique (MTT). This was attributed to the fact that the MFT gave actual count of colonies that was formed, while the result of MTT was approximate value obtained from statistical table, based on the number of tube showed positive showed positive result in each dilution.

\section{CONCLUSION}

From the experimental result and analysis obtained and evaluated, it could be observed that the imported MacConkey broth did yield higher number for total coliform and lower for faecal coliform per $100 \mathrm{ml}$. This was attributed to the compounding of the imported broth. The 
imported broth seems to be more compounded (mix) than the locally prepared broth. Other factors were the inconsistency in weighing the component that constitute the locally prepared broth, $\mathrm{pH}$ and temperature.

From the analysis, the membrane filtration technique (MFT), was found to be more precise, simpler and quicker in enumerating Coliform bacteria than the multiple tube technique (MTT). This is so because the membrane filtration method gives the actual counts of the colonies being formed per $100 \mathrm{ml}$, while the multiple tube technique gives result based on comparing the number of tubes that are positive with approximated values from a standard statistical table (MPN Table).

It was also observed that the BOD, DO, TDS, $\mathrm{pH}$ had low values. This was as a result of preliminary treatment of the wastewater before being discharged into water bodies. 

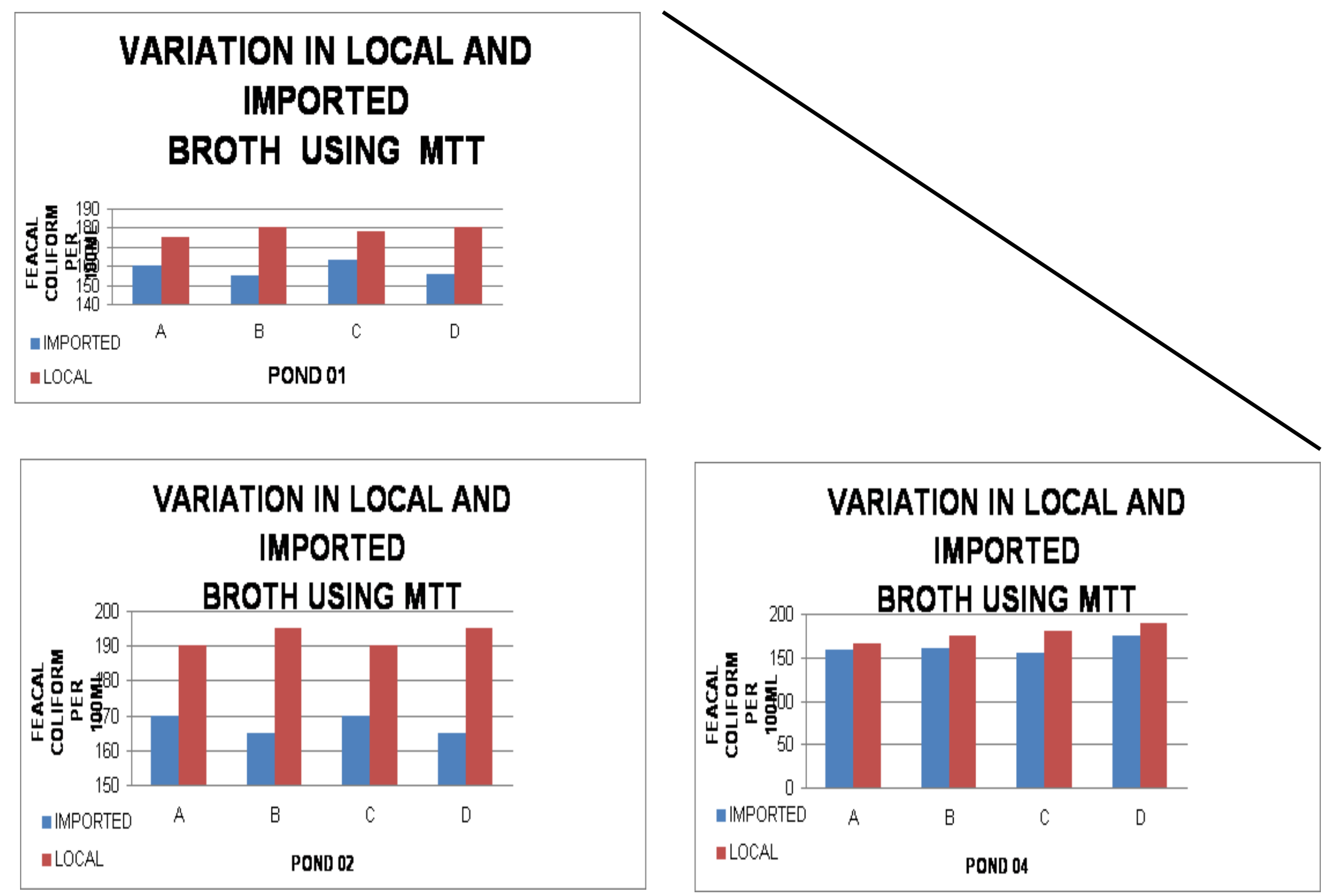

FIGURE 2: VARIATION OF FEACAL COLIFORM IN LOCAL AND IMPORTED BROTH USING MTT 

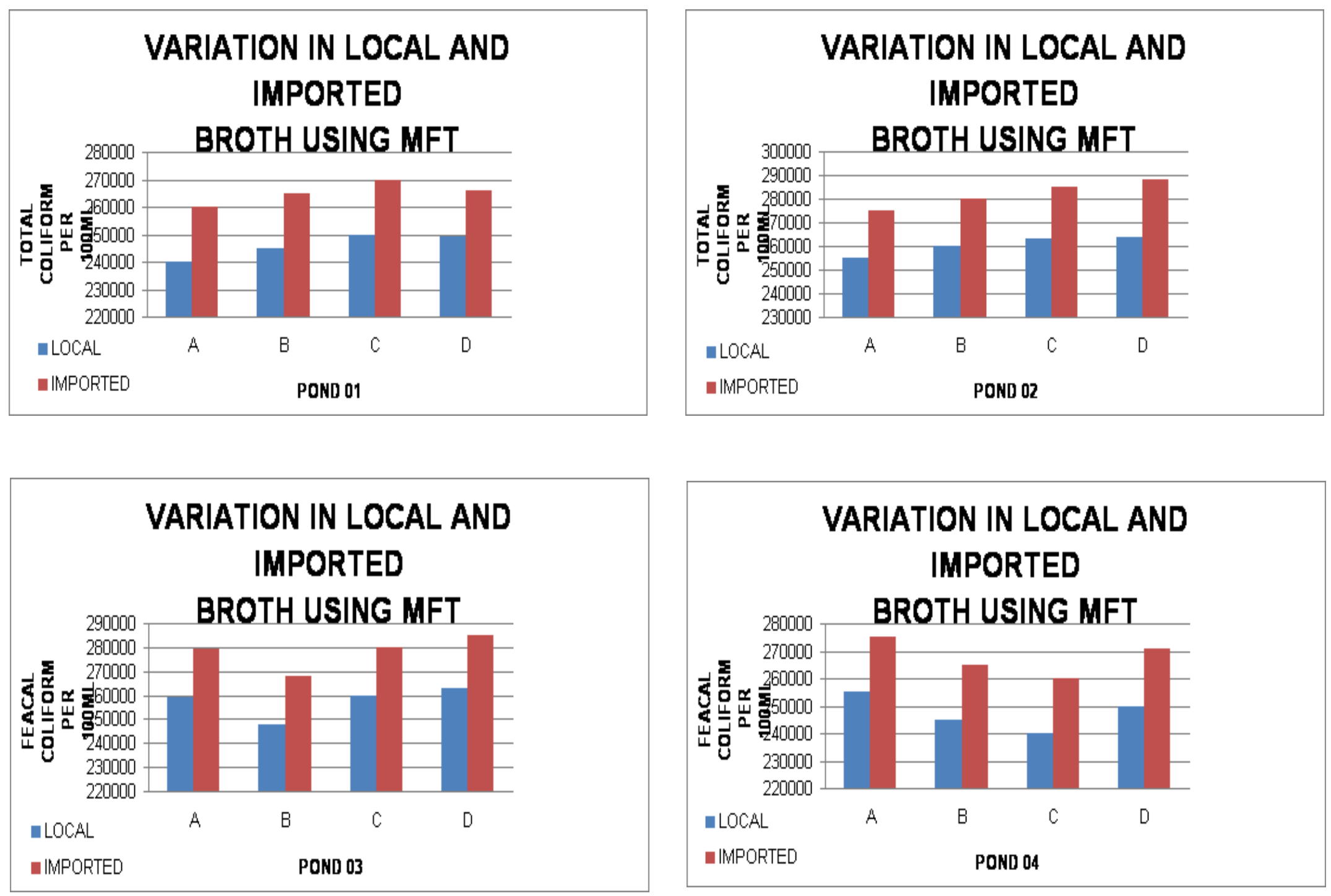

FIGURE 3: VARIATION OF TOTAL COLIFORM IN IMPORTED AND LOCAL BROTH USING MFT 


\section{REFERENCES}

Ackman, D., Marks, S., Mack, P., Caldwell, M., Root, T and Birkhead, G., 1997. Swimmingassociated heamorrhagic colitis due to Escherichia coli 0157:H7 infection, evidence of prolonged contamination of a freshwater lake. Epidemiol infect. 119, 18.

Agunwamba, J. C., 2001. Water Engineering and Management Tool. Immaculate Publications, Enugu. Pp. 117.

Altherholt, T., Feerst, E., Havendon, B., Kwak, J and Rosen J. D., 2003. Evaluation of indicators of faecal contamination in groundwaters. J. Am. Water Works Assoc., 95:115-131.

APHA., 1992. Standard Method for the examination of water and wastewater, $18^{\text {th }}$ edition.

APHA, AWWA and WEF., 2005. Standard methods for the examination of water and wastewater. $21^{\text {st }}$ edition. American Public Health Association. American water works Association and water Environment Federation. Washington, DC.

Bartram, J and Rees, G., 2000. Monitorng bathing waters. E. \& FN Spon, New York, New York.

Duguid, R., 1978. Water Quality and public health water pollution control 9, pp. 360-365.

Frank, E., 2002. Microbiological analysis of Mkpat Enin stream, A B.Sc. Thesis, University of Uyo.

Geldreich, E. E., 1978. "Bacterial pollution and indicator concepts in feces, sewage, storm water, and solid wastes". IN indicators of viruses in water and food (ed. G.Berg), pp. 51-97, Ann Arbor science, Ann Arbor, MI.

Inyang, I. T., 2004. Assessment of waterwells in Ekpri Nsukara, An unpublished students B.Eng. Project. University of Uyo, Uyo. Pp. 44-45.

Keen, W. E., William, E. C., Calderon, M. A and Fleming, D. W., 1994. "A swimming - associated outbreak of hemorrhagic colitis caused by Escherichia coli 015:H7 and shigella sonnei”. New England Journal Med. 331, pp. 579-584.

Kogure, K and Ikemoto, E., 1997. "Wide occurrence of enterohemonagic Escherichia coli 0157 in Natural freshwater environment". Journal of Bacteriology 52, pp. 601-607.

Mates, A., 1983. Rapid Differentiation of streptococci feacalis var liquifasciens from other fecal streptococci in water testing. Journal of water pollution control. Fed. 55, pp. 1211.

Ohno, A., Castrol, E. S., Reyes, A. A and Yamaguchi, K., 1997. "Enteropathogenic bacteria in the La Paz river of Bolivia". American Journal of tropical medical hygiene 578 . Pp. 438-444.

Voelker, R., 1996. "Lake-associated outbreak of Escherichia coli 0157:H7 in Illinois", in 1995 Journal of American Medical Association Vol. 5, pp. 275. 